\title{
ДОСВІД ТА ПЕРСПЕКТИВА ВИКЛАДАННЯ ДИСЦИПЛІНИ “МЕДИЧНА ХІМІЯ” У МЕДСЕСТЕР-БАКАЛАВРІВ ДИСТАНЦІЙНОЇ ФОРМИ НАВЧАННЯ
}

I. I. Герасимець

ДВНЗ “Тернопільський держсавниймедичний університет імені І. Я. Горбачевського МОЗ Украйни”

\section{EXPERIENCE AND PERSPECTIVE OF TEACHING THE DISCIPLINE "MEDICAL CHEMISTRY" IN NURSING BACHELORS OF DISTANCE FORM OF EDUCATION}

\author{
I. I. Herasymets \\ SHEI "Ternopil State Medical University by I. Ya. Horbachevsky of MPH of Ukraine"
}

\begin{abstract}
На сучасному етапі відбуваються кардинальні зміни в способах поширення та використання інформації, що зумовлюють еволюцію освітніх технологій, сприяють активному впровадженню дистанційної освіти як одного $з$ напрямів реформування і стратегічного розвитку освітньої системи України. В умовах ринкової економіки, інформаційно-технологічного розвитку посилюються вимоги до освіченості, професіоналізму фахівців всіх рівнів підготовки. Саме тому сьогодні зроблена величезна ставка на дистанційну форму навчання, яку спеціалісти зі стратегічних проблем освіти називають освітньою системою XXI століття.

At the present stage there are dramatic changes in the methods of dissemination and use of information, contributing to the evolution of educational technologies, help to active introduction of the distance education as one of the directions of the reform and strategic development of the education system of Ukraine. In conditions of the market economy, information and technological development, requirements to the education, to professionalism of specialists of all levels of training are increasing. That is why, today made a huge bet on the distance learning, which specialists on strategic issues of education called the educational system of the XXI century.
\end{abstract}

Вступ. Одним із основних завдань модернізації освіти є розробка та вдосконалення науково-методичного забезпечення викладання дисциплін, покращення організації самостійної та індивідуальної роботи студентів, розробка та впровадження нових ефективних засобів контролю їх якості знань. Проблема доступності освітніх послуг у сучасних умовах є особливо актуальною.

Для підвищення якості та інтенсивності навчального процесу пріоритетним $€$ застосування інформаційно-комунікаційних технологій (IКТ). Особливо важливе використання IКТ, коли йдеться про дистанційну форму навчання [1].

Наше завдання - за допомогою IKT розширити можливості навчального процесу, зробити його більш інформативним та цікавим, створити підгрунтя для індивідуальної роботи студента та його самонавчання.

Основна частина. Дистанційне навчання (ДН) включає сукупність інформаційних технологій та комп’ютерних телекомунікацій, що забезпечують до-

(ㄱ I. I. Герасимець ставку тим, хто навчається, основного обсягу потрібного матеріалу, інтерактивну взаємодію студентів і викладачів у процесі навчання. Завдяки дистанційній формі навчання, студенту надається можливість самостійної роботи з освоєння досліджуваного матеріалу. Така форма навчання $є$ новим способом реалізації освітнього процесу, в основу якого входить використання сучасних IКТ, що дозволяють навчати на відстані за відсутності викладача [2].

Основними перевагами електронного навчання $\epsilon$ цілеспрямована й контрольована інтенсивна самостійна робота студента, який може без допомоги викладача визначати послідовність освоєння предметів, навчатися в зручному для себе місці, з індивідуальною швидкістю, а в ряді випадків - у зручний для себе час. ДН має більш індивідуальний характер, $\epsilon$ гнучкішим, студент може сам визначити темп навчання, повертатися по кілька разів до окремих занять, пропускати окремі розділи і т. д. Слухач вивчає навчальний матеріал в процесі всього часу навчання, а не тільки в період сесії, що гарантує більш 
глибокі знання. Така система навчання змушує студента займатися самостійно і набувати навички самоосвіти.

Основними принципами дистанційної освіти є практично необмежене тиражування освітніх програм без втрати їх якості. Як відомо, джерелом інформації і методичного забезпечення при дистанційній освіті $€$ не викладачі, а навчальні і навчально-методичні матеріали, що одержують студенти і слухачі упродовж навчання, і які включають практично все, що необхідно для успішного завершення навчання з даної дисципліни. Навчання основане на принципі тісного зв'язку між студентом, який хоче навчатися самостійно, і координатором навчання - викладачем. Роль викладача в цій системі зводиться до координації і допомоги в засвоєнні матеріалу [3].

У системі ДН використовуються мережеві технології забезпечення навчального процесу, що дозволяють одночасно, за одними і тими ж програмами проводити навчання студентів у будь-якій кількості регіонів. Організація процесу навчання проводиться на місцях локальними центрами, що забезпечують методичний і технічний зв' язок з центральним вузом надавачем освітніх послуг.

Система процедур, яка використовується при мережевих методах навчання, є гарантією забезпечення рівної якості донесеної до студентів інформації у всіх регіонах, що підтримується централізованою підготовкою викладачів, їх періодичною перепідготовкою, постійним моніторингом і всією системою адміністративного (електронний деканат), методичного (система знань), й інформаційного (програмна оболонка) забезпечення навчального процесу.

Виконання цих принципів є передумовами єдиної державної освітньої політики у сфері дистанційного навчання [3].

Нові електронні технології можуть не тільки забезпечити активне залучення студентів у навчальний процес, але і дозволяють керувати цим процесом на відміну від більшості традиційних навчальних середовищ. Подальший розвиток системи ДН потребує забезпечення максимальної інтерактивності. Навчання тільки тоді може бути повноцінним, коли досягається імітація реального спілкування з викладачем. Необхідно використовувати поєднання різних типів електронних комунікацій, що дозволило б компенсувати недолік особистого контакту за рахунок віртуального спілкування. Безперечно, прогресивним є використання мультимедійних он-лайн лекцій у процесі вивчення дисципліни “Медична хімія". Ці інтерактивні можливості, які використовуються в системі дистанційного навчання ДВНЗ “Тернопільський державний медичний університет імені І. Я. Горбачевського MO3 України", програми і системи доставки інформації дозволяють налагодити і навіть стимулювати зворотний зв' язок, забезпечити діалог і постійну підтримку студентів.

Після аналізу існуючих систем і особливостей підготовки для них дистанційних курсів стала очевидною перевага орієнтації на власні розробки, які б давали можливість розділити цю роботу на дві складові, що виконувались би двома виконавцями.

Розробник дистанційного курсу - найбільш кваліфікований викладач-лектор - готує методичні матеріали в чітко обумовленому структурованому вигляді, так, як це зручно для подальшої обробки, а кваліфікований програміст переводить цей матеріал у форму, яка вбудовується у програмну платформу системи ДН [4].

На нашу думку, лише таким чином можна швидко розгорнути систему, орієнтовану не на створення окремих, не зв' язаних між собою дистанційних курсів (нащопішли більшість вітчизняних вузів), анапідготовку студентів за цілим комплексом спеціальностей.

Система дистанційного навчання, на наш погляд, для свого функціонування має складатися із нижченаведених обов'язкових частин.

1. Запис на навчання - передбачає можливість будь-кому, з будь-якої точки світу через Інтернет записатися на одержання бажаної спеціальності або вивчення окремого курсу (модуля), одержати електронною поштою договір з умовами навчання, його роздрукувати, підписати i, одержавши пароль та логін, мати доступ до необхідних інформаційних матеріалів і ресурсів.

2. Дистанційне навчання є найбільш ефективним, коли освітні послуги надаються за місцем проживання студента.

3. База знань, яка в свою чергу складається з інформаційних матеріалів, що представлені у вигляді чітко визначеної послідовності програми дій студента, при виконанні якої він гарантовано освоює дану дисципліну (траєкторія навчання, що відслідковується системою, викладачем і електронним деканатом). Крім того, студент має виконати індивідуальне завдання у вигляді контрольної чи курсової роботи (проекту) і надіслати його викладачу на перевірку, а потім захистити перед викладачем, працюючи в режимі он-лайн.

Дисципліна “Медична хімія" передбачає виконання лабораторних робіт для одержання необхідних для освоєння предмета навичок і вмінь. Для цього передбачаються віртуальні практичні навички, що іміту- 
ють всі дії студента, які б він виконував на реальній лабораторній роботі.

Очевидно, що система дистанційного навчання лише тоді буде конкурентоспроможною $з$ іншими системами, коли забезпечуватиме необхідну якість знань. Для цього в ній має функціонувати розвинута структура контролю якості засвоєння знань. Вона передбачає: тематичні контролі, які студент складає після вивчення відповідних тем в режимі прямого зв'язку через Інтернет з тестуючою програмою, розміщеною на сервері ДН вузу. Для он-лайн тестування $з$ дисципліни "Медична хімія" використовують систему електронного контролю знань Moodle.

Тести успішності повинні відповідати ряду вимог. Вони повинні бути: відносно короткотерміновими, тобто не вимагати значних затрат часу, однозначними, тобто не допускати вільного тлумачення тестового завдання; правильними, тобто виключати можливість формулювання багатозначних відповідей. Результати цих контролів (тестувань) записуються в навчальний журнал студента і дають інформацію викладачу про хід освоєння навчального процесу конкретним студентом, а також використовуються ним для рейтингової системи оцінки знань і корегування освітньої траєкторії.

Підсумковий контроль (залік чи екзамен) проводиться тільки очно, спеціально уповноваженим представником університету, який має заздалегідь підготовлену комп'ютерну тестувальну програму.

Результати тестування в електронному вигляді розгорнутого протоколу відповідей записуються у комп'ютерну базу даних і відмічаються у персональній заліковій книжці студента.

4. База даних системи дистанційного навчання разом із внутрішньою системою документообігу вклю-

\section{Література}

1. Филоненко С. Н. Дистанционное образование на Украине: опыт и перспективы / С. Н. Филоненко // Зб. наук. праць МАУП.-Київ, 2009.-С. 9-14.

2. Биков В. Ю. Відкрита освіта і відкрите навчальне середовище / В. Ю. Биков // Теорія і практика управління соціальними системами. - 2008. - № 2. - С. 116-123. чає в себе взаємопов'язану інформацію персональної сторінки студента, викладача, який веде всіх студентів, що вивчають даний предмет, та системи електронного деканату, де фіксуються всі етапи навчання студента, робочі та індивідуальні навчальні плани студентів, система електронної пошти, запис результатів спілкування в chat, он-лайн лекції, Інтернет-конференції тощо.

Одержаний досвід ДВНЗ “Тернопільський державний медичний університет імені І. Я. Горбачевського МОЗ України" свідчить про значну перспективність такої форми навчання, особливо для тих категорій населення, які раніше за різними обмеженнями не могли навчатися ні на очній, ні на заочній формах навчання.

Висновки. Необхідність змін у системі медичної освіти обумовлена численними факторами: стрімким зростанням обсягів медичної інформації, швидкою зміною та розширенням наших уявлень про патогенез багатьох патологій, недостатністю часу на освоєння великого масиву необхідної інформації, нескінченною різноманітністю фізіологічних та патологічних станів людського організму. Варто також відзначити, що входження нашої країни у світове співтовариство неможливе без модернізації системи вищої освіти, спрямованої на підготовку фахівців на рівні міжнародних вимог.

Безперечними перевагами дистанційного навчання є більш висока ефективність професійної підготовки порівняно з вечірньою та заочними формами навчання при більш низькій вартості освітніх послуг, скорочення термінів навчання, можливості паралельного навчання в українському та зарубіжному вузах, незалежність студента від географічного розташування вузу.

3. Клокар Н. Методологічні основи запровадження дистанційного навчання в системі підвищення кваліфікації / Н. Клокар // Шлях освіти. -2007. - № 4 (46). - С. 38-41.

4. Про затвердження Державної програми “Інформаційні та комунікаційні технології в освіті і науці” на 2006 -2010 роки : Постанова КМУ від 7 грудня 2005 р. № 1153. 